\title{
ANALISIS WACANA “DEBAT CAPRES-CAWAPRES 2019” DAN IMPLIKASINYA DALAM MATA KULIAH PRAGMATIK
}

\author{
Aida Azizah \\ PBSI, FKIP, UNISSULA \\ Email: aidaazizah@unissula.ac.id
}

\begin{abstract}
Abstrak
Analisis melalui tinjauan wacana merupakan salah satu kegiatan praktik dalam pembelajaran mata kuliah pragmatik. Ruang lingkup permasalahan dalam penelitian ini adalah tinjauan analisis dalam wacana "Debat Capres-Cawapres 2019". Penelitian ini dirancang untuk mendeskripsikan hasil analisis yang terdapat dalam wacana. Penelitian ini menggunakan data penelitian tentang bentuk penggunan bahasa yang digunakan dalam komunikasi. Sumber data yang akan digunakan dalam penelitian ini adalah wacana "Debat Capres-Cawapres 2019". Metode penelitian ini menggunakan metode qualitative-descriptive research. Subjek penelitian ini yakni Mahasiswa PBSI FKIP UNISSULA. Teknik pengumpulan data dilakukan melalui analisis wacana "Debat Capres-Cawapres 2019". Dalam penelitian ini menggunakan teknik analisis data dengan model siklus interaktif berupa penyajian data kemudian melakukan penarikan kesimpulan. Hasil penelitian akan diimplikasikan dalam mata kuliah Pragmatik PBSI FKIP UNISSULA

Kata Kunci: Analisis Wacana dan Pragmatik
\end{abstract}

\begin{abstract}
Analysis through discourse review is one of the practical activities in learning pragmatic subjects. The scope of the problem in this study is a review of the analysis in the discourse "2019 Presidential Candidates-Presidential Candidates". This study was designed to describe the results of the analysis contained in the discourse. This study uses research data on the form of language used in communication. The data source that will be used in this study is the discourse "2019 Presidential Candidates-Presidential Debate". This research method uses qualitative-descriptive research method. The subjects of this study were PBSI FKIP UNISSULA students. Data collection techniques were carried out through the discourse analysis "2019 Presidential Candidate-Presidential Debate". In this study using data analysis techniques with interactive cycle models in the form of data presentation then draw conclusions. The results of the study will be implicated in the Pragmatic PBSI FKIP UNISSULA course
\end{abstract} Keywords: Discourse and Pragmatic Analysis 


\section{PENDAHULUAN}

Bahasa merupakan media utama yang digunakan manusia (masyarakat) dalam kegiatan komunikasi sehari-hari. Berpijak dari pengertian tersebut, maka dapat diketahui tentang pengertian Bahasa dalam istilah lain, bahwa bahasa itu bagian utama dari salah satu alat komunikasi yang penting dalam kehidupan bermasyarakat (manusia). Melalui bahasa manusia dapat berkomunikasi dengan mudah, bertukar pikiran, serta gagasan. Kemampuan dalam menyampaikan pesan atau informasi secara tepat (sesuai) menggunakan pilihan bahasa yang baik dan benar itu perlu dilakukan ketika berkomunikasi. Pernyataan ini disampaikan dengan maksud supaya pesan atau informasi yang akan tersampaikan kepada pihak (orang) lain itu akan lebih mudah dimengerti secara baik dan tepat (sesuai) dengan tujuan yang telah direncanakan.

\section{Berbagai}

cara penggunaan bahasa yang digunakan oleh seseorang akan dapat menyampaikan gagasan atau idenya baik dengan cara lisan maupun tulisan baik dalam acara formal maupun non formal. Penggunaan bahasa yang digunakan dalam debat Capres Cawapres 2019 merupakan tuturan yang digunakan untuk . mengemukakan ekspresi dari masing-masing calon kepada warga Negara Indonesia. Wacana "Debat Capres - Cawapres 2019" dijadikan objek dalam penelitian ini. Kajian yang akan dijadikan bahan dalam penelitian ini adalah tuturan yang tertulis pada wacana dengan menggunakan kajian pragmatik.

Pragmatik menurut Levinson yaitu "Pragmatics is the study of the relation between language and context that are basic to an account of language understanding". Pengertian pragmatik menurut Levinson tersebut mengemukakan bahwa dalam kegiatan memahami penyampaian makna yang terkandung dalam bahasa yang disampaikan oleh seorang ketika berkomunikasi itu seharusnya dituntut supaya tidak hanya dapat mengerti makna yang akan disampaikan dan memahami hubungan unsur gramatikal antara setiap kata yang telah disampaikan, namun juga harus dapat memberikan kesimpulan tentang hubungan antara Bahasa apa yang telah diucapkan dengan makna apa yang telah diasumsikan oleh seorang penutur, ataupun tentang penggunaan bahasa yang telah diucapkan oleh penutur sebelumnya. Wacana "Debat Capres - Cawapres 2019 secara tidak langsung memiliki tujuan dalam memberikan himbauan dan juga informasi kepada masyarakat. Dalam penggunaan bahasa yang telah digunakan pastinya terdapat sebuah maksud dan tujuan yang ingin disampaikan baik secara tersirat maupun tersurat. Maksud dan tujuan tersebut dapat kita pelajari dari cabang ilmu linguistik yakni pragmatik. 
Kajian bidang ilmu tentang pragmatik yang sangat luas dijadikan dasar utama peneliti ketika melakukan penelitian ini, namun peneliti membatasi ruang lingkup kajian hanya pada kajian tindak tutur. Dalam upaya untuk memahami setiap konsep dari penelitian ini maka diperlukan suatu pemahaman yang lebih lanjut, sehingga dengan terdapatnya hasil penelitian ini diharapkan akan mendapatkan sebuah kajian pragmatik yang dapat dilkukan dengan mengupas bahan kajian tindak tutur secara lebih luas berdasarkan teori-teori dan referensi-referensi yang mendukung dalam penelitian ini. Oleh sebab itu, peneliti bermaksud akan melakukan penelitian dengan judul Tinjauan Analisis pada Wacana "Debat Capres dan Cawapres 2019" dan Implikasinya dalam Mata Kuliah Pragmatik PBSI FKIP UNISSULA.

\section{METODE PENELITIAN}

Penelitian ini menggunakan metode qualitative descriptive research (Creswell, 2009). Kajian dalam penelitian ini telah dirancang untuk dapat memberikan deskripsi atau memberikan penjelasan tentang jenis tindak tutur yang terdapat dalam kegiatan komunikasi pada Wacana "Debat Capres dan Cawapres 2019” dan mendeskripsikan implikasi hasil penelitian dalam proses pembelajaran Mata Kuliah Pragmatik, PBSI FKIP UNISSULA

\section{HASIL DAN PEMBAHASAN}

Penelitian ini melakukan analisis pada dua wacana. Wacana pertama "Sandiaga Janjikan 15 Juta Lapangan Kerja Jika jadi Wapres" ditemukan 5 (lima) Jenis tindak tutur yakni komisif menjanjikan, asertif memberitahu, asertif mengeluh, direktif memohon, dan komisif berjanji. Wacana kedua "PD Kritik Prabowo yang Singgung 'Presiden Sebelumnya' Di Debat" telah ditemukan 2 (dua) jenis tuturan yang digunakan yakni dikemukakan secara tidak langsung dan dikemukakan secara asertif menyatakan. Hasil analisis dari dua wacana tersebut akan diimplikasikan dalam mata kuliah pragmatik. Masing-masing akan diuraaikan sebagai berikut.

\subsection{Bentuk tindak tutur dalam wacana "Sandiaga Janjikan 15 Juta Lapangan Kerja Jika jadi Wapres"}

Wacana pertama yang digunakan dalam penelitian ini dipublikasikan pada hari Sabtu, tanggal 13 April 2019, pukul 22:38 WIB, oleh Dwi Andayani-detik News. Hasil analisis bentuk tindak tutur yang ditemukan dalam wacana tersebut telah ditemukan 9 data yang akan diuraikan sebagai berikut.

"Prabowo-Sandi berkomitmen I5 juta lapangan kerja baru akan diciptakan". (D_OI) 
Kutipan data di atas, penutur (Sandiaga) bermaksud memberikan janji kepada rakyat akan menciptakan sebanyak 15 juta lapangan pekerjana, jika beliau lolos terpilih dan menjadi wakil presiden pada tahun 2019. Data tersebut tergolong tindak tutur komisif bermakna berjanji, dengan penanda lingual "Prabowo-Sandi berkomitmen".

"Sektor-sektor perumahan juga bisa menciptakan 4 juta lapangan pekerjaan baru. Gerakan OK OCE menargetkan 2 juta pengusaha baru yang akan membuka lapangan kerja untuk anak muda". (D_02)

Kutipan data di atas penutur (Sandiaga) bermaksud memberitahu kepada rakyat bahwa selain 15 juta lapangan pekerjaan yang diciptakan, juga akan dibangun sektor perumahan yang akan diciptakan hingga 4 juta peluang pekerjaan baru, begitu juga gerakan tentang OK OCE juga sudah ditargetkan antara 2 juta pengusaha-pengusaha baru untuk anak muda. Tindak tutur asertif memberitahu, terbukti dengan penanda lingual pada "kalimat pertama”.

"Anak muda kita banyak yang menganggur”. (D_03)

Kutipan data di atas tergolong tindak tutur asertif mengeluh. Penutur (Sandiaga) mengeluhkan anak muda yang tidak mendapatkan lapangan pekerjaan dalam artian menganggur, maka dari itu jika penutur terpilih menjadi wakil presiden 2019, penutur akan menciptakan lapanagn pekerjaan yang lebih banyak dari tahun-tahun sebelumnya.

"Kita ingin $4 I$ persen anak muda kita ini mendapatkan link and match melalui Rumah Siap Kerja.” (D_04)

Kutipan data di atas dikategorikan dalam tindak tutur direktif memohon, Banyaknya kasus anak muda yang menganggur, maka penutur (Sandiaga) menginginkan supaya anakanak muda berhak mendapatkan kesempatan dalam memperoleh pekerjaan baru melalui program yang telah direncanakan. Rumah Siap Kerja adalah rancangan program baru yang diluncurkan oleh pasangan capres-cawapres PrabowoSandi yang dapat menciptakan lapangan pekerjaan baru.

"Kami kaget bahwa
Instagram Rumah Siap Kerja
mendapat antusiasme dari
anak muda yang ingin
mendapatkan pekerjaan".
(D_05)

\begin{tabular}{lrr}
\multicolumn{1}{c}{ Kutipan tuturan yang } \\
disampaikan $\quad$ di & atas \\
merupakan jenis tindak tutur \\
asertif mengeluh, karena \\
penutur \\
(Sandiaga)
\end{tabular}


memberitahu kepada audiens bahwa akun instagarm Rumah Siap Kerja mendapat antusiasme yang tinggi dari berbagai anak muda. Sandiaga merasa kaget karena Rumah Siap Kerja merupakan progam baru yang akan diluncurkan.

$\begin{array}{lr}\text { "Visi-misi } & \text { kami } \\ \text { mengutamakan } & \text { kesetaraan } \\ \text { gender". (D_06) } & \end{array}$

Kutipan tuturan yang dikemukakan di atas tergolong jenis tindak tutur asertif memberitahu, penutur ( Ma'ruf Amin) bermaksud memberitahu kepada audiens terkait visi misinya yakni mengutamakan kesetaraan gender. Pasangan Joko Widodo-Ma'ruf Amin berusaha akan menyetarakan gender perempuan sebanding dengan laki-laki, bukan hanya saja dalam hal bidang perekonomian dan politik, melainkan juga akan menyetarakan dalam hal bidang pemerintahan.

"Kami akan berusaha
semaksimal mungkin agar
perempuan tidak hanya
dibidang ekonomi, politik,
tetapi juga dibidang
pemerintahan," (D_07)

Kutipan pada tuturan yang dikemukakan di atas termasuk jenis tindak tutur komisif berjanji, penutur bermaksud ingin menjanjikan kepada rakyat, jika penutur (Ma'ruf Amin) terpilih menjadi Wakil Presiden 2019, penutur akan menyeimbangkan kesetaraan gender diantara seorang lakilaki dan seorang perempuan, khususnya dalam hal dibidang pemerintahan.

"Saya tahu persis
nasabahnya 100 persen
adalah perempuan. Bahkan
beribu-ribu merasa tertolong,
bangga, bukan hanya cita-
cita,". (D_08)

$\begin{array}{crr}\text { Kutipan } & \text { tuturan } & \text { yang } \\ \text { dikemukakan } & \text { di } & \text { atas }\end{array}$ tergolong jenis tuturan asertif mengeluh. Pada tuturan yang dikemukakan oleh penutur (Ma'ruf Amin) bermaksud mengeluh atas ketidaksetaraan gender yang ada di Indonesia ini, kebanyakan kaum wanita yang bekerja di bidang ekonomi, bahkan kaum wanita merasa bangga dengan posisi yang sudah didapat. Padahal penutur (Ma'ruf Amin) sangat menyayangkan hal tersebut. Oleh karena itu, jika Ma'ruf Amin terpilih menjadi wapres 2019, beliau hendak mewujudkan Indonesia dengan kesetaraan gender, supaya kaum wanita bukan hanya menduduki sector ekonomi dan politik, melainkan juga ikut berbaur di sektor pemerintahan.

"Upaya ini akan terus kami bangun di desa-desa, akan kami ciptakan namanya Dewi-dewi dan Dedi-dedi,". (D_09) 
Kutipan tuturan yang dikemukakan di atas tergolong jenis tuturan komisif menjanjikan. Tuturan yang dikemukakan oleh penutur (Ma'ruf Amin) bermaksud menyampaikan janji kepada audiens dan seluruh rakyat Indonesia, jika nanti terpilih menjadi wakil presiden 2019, penutur akan menciptakan dua program yaitu desa wisata dan desa digital, dimana kedua program tersebut sangat mengedepankan perempuan dalam hal ekonomi.

\subsection{Bentuk tindak tutur dalam wacana "PD Kritik Prabowo yang Singgung 'Presiden Sebelumnya' Di Debat"}

Wacana kedua yang digunakan dalam penelitian ini dipublikasikan pada hari Sabtu, tanggal 13 April 2019, pukul 22:20 WIB, oleh Idam Kholid-detik News. Hasil analisis bentuk tindak tutur yang ditemukan dalam wacana tersebut telah ditemukan 2 data yang akan diuraikan sebagai berikut.

\section{"Pak Prabowo sebenarnya sedang berdebat dengan siapa?”. (D_0l0)}

Kutipan tuturan yang dikemukakan di atas tergolong jenis tuturan yang disampaikan dengan tidak langsung, tuturan telah dikemukakan penutur (Wasekjen PD Rachlan
Nashidik) yang menyampaikan tuturannya menggunakan kalimat pertanyaan, terdapat pada lingual "Pak Prabowo sebenarnya sedang berdebat dengan siapa?",. Tuturan tersebut disampaikan secara tidak langsung, hal itu terlihat dalam kalimat tersebut yang maknanya tidak sekadar bertanya melainkan penutur (Rachlan Nashidik) mengkritik Bapak Prabowo, karena selalu menyinggung presiden sebelumnya, bukan Bapak Jokowi yang menjadi lawan debatnya.

"Saya tidak menyalahkan Bapak, ini kesalahan besar presiden-presiden sebelum Bapak”. (D_0II)

Kutipan tuturan di atas tergolong tindak tutur asertif menyatakan. tertanda pada lingual "saya tidak menyalahkan Bapak..." karena sebelumnya telah dijelaskan mengenai impor yang masih saja diperbolehkan masuk ke Indonesia, bahwa Bapak Prabowo tidak menyalahkan Bapak Jokowi, melainkan kesalahan presiden-presiden sebelumnya.

\subsection{Implikasi dalam Mata Kuliah Pragmatik PBSI FKIP UNISSULA}

Bentuk tindak tutur dalam wacana debat capres dan cawapres 2019 dapat 
diimplikasikan dalam mata kuliah pragmatik PBSI FKIP UNISSULA. Mata kuliah pragmatik merupakan salah satu materi yang menekankan mahasiswa untuk mengetahui jenis-jenis tindak tutur disertai aplikasinya dalam kehidupan sehari-hari. Sesuai dengan pernyataan tersebut, hasil dari penelitian ini dapat dimanfaatkan dalam kegiatan pembelajaran. Salah satunya sebagai alternatif yang berupa penggunaan bahan ajar dalam proses kegiatan pembelajaran bahasa, selain itu hasil penelitian ini secara umum juga dapat memberikan sumbangan yang dapat dimanfatkan dalam setiap aspek kognitif. Sumbangan dalam aspek kognitif didapatkan dari proses pembelajaran yang berupa pengetahuan/wawasan

mahasiswa terhadap pembelajaran mata kuliah pragmatik semakin meningkat, khususnya pendalaman materi sehingga membantu mahasisswa dalam pemahaman teori tentang tindak tutur. dan dapat digunakan sebagai bekal serta bahan/referensi mahasisswa sebagai calon pendidik untuk penerapanya di sekolah. Berikut akan dipaparkan hasil tindak tutur dalam wacana "Debat Capres dan Cawapres 2019" yang akan diimplikasikan dalam pembelajaran Mata Kuliah Pragmatik PBSI FKIP UNISSULA.
Tabel 1. Hasil Bentuk Tindak Tutur

\begin{tabular}{|c|c|c|}
\hline NO & TUTURAN & $\begin{array}{l}\text { TINDAK } \\
\text { TUTUR }\end{array}$ \\
\hline 1. & $\begin{array}{l}\text { "Prabowo- } \\
\text { Sandi } \\
\text { berkomitmen } \\
15 \text { juta } \\
\text { lapangan kerja } \\
\text { baru akan } \\
\text { diciptakan". }\end{array}$ & $\begin{array}{l}\text { Komisif } \\
\text { Menjanjikan }\end{array}$ \\
\hline 2. & $\begin{array}{l}\text { "Sektor-sektor } \\
\text { perumahan } \\
\text { juga bisa } \\
\text { menciptakan } 4 \\
\text { juta lapangan } \\
\text { pekerjaan } \\
\text { baru. Gerakan } \\
\text { OK OCE } \\
\text { menargetkan } 2 \\
\text { juta pengusaha } \\
\text { baru yang akan } \\
\text { membuka } \\
\text { lapangan kerja } \\
\text { untuk anak } \\
\text { muda". }\end{array}$ & $\begin{array}{l}\text { Asertif } \\
\text { Memberitahu }\end{array}$ \\
\hline 3. & $\begin{array}{l}\text { "Anak muda } \\
\text { kita banyak } \\
\text { yang } \\
\text { menganggur". }\end{array}$ & $\begin{array}{l}\text { Asertif } \\
\text { Mengeluh }\end{array}$ \\
\hline 4. & $\begin{array}{l}\text { "Kita ingin } 41 \\
\text { persen anak } \\
\text { muda kita ini } \\
\text { mendapatkan } \\
\text { link and match } \\
\text { melalui Rumah } \\
\text { Siap Kerja." }\end{array}$ & $\begin{array}{l}\text { Direktif } \\
\text { Memohon }\end{array}$ \\
\hline 5. & $\begin{array}{l}\text { "Kami kaget } \\
\text { bahwa } \\
\text { Instagram } \\
\text { Rumah Siap } \\
\text { Kerja } \\
\text { mendapat }\end{array}$ & $\begin{array}{l}\text { Asertif } \\
\text { Memberitahu }\end{array}$ \\
\hline
\end{tabular}




\begin{tabular}{|c|c|c|}
\hline & $\begin{array}{l}\text { antusiasme } \\
\text { dari anak muda } \\
\text { yang ingin } \\
\text { mendapatkan } \\
\text { pekerjaan". }\end{array}$ & \\
\hline 6. & $\begin{array}{l}\text { "Pak Prabowo } \\
\text { sebenarnya } \\
\text { sedang } \\
\text { berdebat } \\
\text { dengan siapa?" }\end{array}$ & $\begin{array}{l}\text { Tindak Tutur } \\
\text { Tidak } \\
\text { Langsung }\end{array}$ \\
\hline 7. & $\begin{array}{l}\text { "Saya tidak } \\
\text { menyalahkan } \\
\text { Bapak, ini } \\
\text { kesalahan } \\
\text { besar } \\
\text { presiden- } \\
\text { presiden } \\
\text { sebelum Bapak }\end{array}$ & $\begin{array}{l}\text { Asertif } \\
\text { Menyatakan }\end{array}$ \\
\hline 8. & $\begin{array}{l}\text { "Visi-misi kami } \\
\text { mengutamakan } \\
\text { kesetaraan } \\
\text { gender". }\end{array}$ & $\begin{array}{l}\text { Asertif } \\
\text { Memberitahu }\end{array}$ \\
\hline 9. & $\begin{array}{l}\text { "Kami akan } \\
\text { berusaha } \\
\text { semaksimal } \\
\text { mungkin agar } \\
\text { perempuan } \\
\text { tidak hanya } \\
\text { dibidang } \\
\text { ekonomi, } \\
\text { politik, tetapi } \\
\text { juga dibidang } \\
\text { pemerintahan," }\end{array}$ & $\begin{array}{l}\text { Komisif } \\
\text { Berjanji }\end{array}$ \\
\hline 10. & $\begin{array}{l}\text { "Saya tahu } \\
\text { persis } \\
\text { nasabahnya } \\
100 \text { persen } \\
\text { adalah } \\
\text { perempuan. } \\
\text { Bahkan beribu- } \\
\text { ribu merasa } \\
\text { tertolong, }\end{array}$ & $\begin{array}{l}\text { Asertif } \\
\text { Mengeluh }\end{array}$ \\
\hline
\end{tabular}

\begin{tabular}{|c|c|c|}
\hline & $\begin{array}{l}\text { bangga, bukan } \\
\text { hanya cita- } \\
\text { cita," }\end{array}$ & \\
\hline 11. & $\begin{array}{l}\text { "Upaya ini } \\
\text { akan terus } \\
\text { kami bangun di } \\
\text { desa-desa, } \\
\text { akan kami } \\
\text { ciptakan } \\
\text { namanya } \\
\text { Dewi-dewi dan } \\
\text { Dedi-dedi," }\end{array}$ & $\begin{array}{l}\text { Komisif } \\
\text { Menjanjikan }\end{array}$ \\
\hline
\end{tabular}

\section{PENUTUP}

Bentuk tindak tutur yang telah penulis temukan dalam wacana "Debat Capres dan Cawapres 2019” yang keseluruannya berjumlah 11 data yang mengandung bentuk komisif menjanjikan, asertif memberitahu, asertif mengeluh, direktif memohon, komisif berjanji, tindak tutur secara tidak langsung, dan asertif menyatakan. Bentuk tindak tutur yang telah ditemukan dapat diimplikasikan pada Mata Kuliah Pragmatik PBSI FKIP UNISSULA.

\section{DAFTAR PUSTAKA}

Creswell. (2009). "Research Design: Qualitative, Quantitative, and Mixed Methods Approaches." Newbury Park: Sage Publications.

Ibrahim, S. (1993). "Kajian Tindak Tutur". Surabaya: Usaha Nasioal. 
Leech, G. (1993). “Prinsip-Prinsip

Pragmatik".

(Terjemahan MDD Oka). Jakarta: Indonesia University Press.

Levinson. (1997). "Pragmatics". Great: Britain: Cambridge University Press.

Mulyana. (2005). “Kajian Wacana Teori, Metode, \& Aplikasi Prinsip-Prinsip Analisis Wacana". Yogyakarta: Tiara Wacana.

Rani, A. dkk. (2006). "Analisis Wacana". Malang: Bayumedia.

Rohmadi, M. (2011). "Pragmatik: Teori dan Analisis." Surakarta: Yuma Pustaka.

Rohmadi, M. (2004). "Pragmatik: Teori dan Analisis". Yogyakarta: Lingkar Media.
Rustono. (1999). "Pokok-pokok Pragmatik". Semarang: IKIP Semarang Press.

Rustono. (2000). "Implikatur Tindak Tutur Humor". Semarang: IKIP Semarang Press.

Sumarlan. (2003). "Teori dan Praktik Analisis Wacana". Surakarta: Pustaka Cakra.

Yule, G. (2006). "Pragmatik". Yogyakarta: Pustaka Pelajar.

\section{PROFIL SINGKAT}

Aida Azizah Lahir di Kabupaten Semarang pada tanggal 16 Januari 1985. Lulus S1 PBSI UNNES pada tahun 2007. Pada tahun 2009 melanjutkan S2 PBI di Pascasarjana UNNES. Kemudian pada tahun 2014 melanjutkan S3 PBI di Pascasarjana UNS. Sekarang berprofesi sebagai Dosen S1 PBSI FKIP UNISSULA dan menjabat sebagai Sekretaris Program Studi PBSI. 